\title{
Chromosome characterization and variability in some Iridaceae from Northeastern Brazil
}

\author{
Lânia Isis F. Alves, Saulo Antônio A. Lima and Leonardo P. Felix \\ Laboratório de Citogenética Vegetal, Setor de Botânica, Departamento de Ciências Biológicas, \\ Universidade Federal da Paraíba, Areia, PB, Brazil.
}

\begin{abstract}
The chromosomes of 15 species of Iridaceae of the genera Alophia, Cipura, Eleutherine, Neomarica and Trimezia (subfamily Iridoideae) were examined after conventional Giemsa staining. The karyotypes of Alophia drummondii $(2 n=14+1 \mathrm{~B}, 28,42$ and 56), Cipura paludosa $(2 n=14), C$. xanthomelas $(2 n=28)$ and Eleutherine bulbosa $(2 n=12)$ were asymmetric; Neomarica candida, $N$. caerulea, $N$. humilis, $N$. glauca, $N$. gracilis, $N$. northiana and Neomarica sp. $(2 n=18) ; N$. cf. paradoxa $(2 n=28)$, Trimezia fosteriana $(2 n=52), T$. martinicensis $(2 n=54)$ and $T$. connata $(2 n=$ 82) were all generally symmetric. New diploid numbers of $2 n=56$ for Alophia drummondii, $2 n=18$ for $N$. candida, $N$. humilis, $N$. glauca, and $N$. gracilis, $2 n=28$ for $N$. cf. paradoxa, and $2 n=82$ for $T$. connata are reported. The karyotypic evolution of the studied species is discussed.
\end{abstract}

Key words: Iridaceae, disploidy, karyotypic evolution, polyploidy, asymmetrical karyotype.

Received: August 13, 2010; Accepted: February 28, 2011.

\section{Introduction}

The monocot family Iridaceae comprises approximately 2050 species distributed among 67 genera, with a major center of radiation in the southern African Sahara (Goldblatt et al., 2008). The Neotropics are considered the second most important center of diversity for this family, with 250 known species and 30 genera; from which 18 genera and 160 species occur in Brazil (Eggers et al., 2010; Judd et al., 2008). Iridaceae is divided into seven subfamilies (Goldblatt et al., 2008); the subfamily Iridoideae, the subject of the present work, is composed of four tribes and includes many exotic species that are cultivated as ornamental plants or to harvest saffron, especially those from the genera Gladiolus, Neomarica, Crocus and Trimezia (Lorenzi and Souza, 2001).

This family is relatively well studied in terms of its cytology, especially the Old World taxa, with diploid numbers reported for 1330 species (almost $65 \%$ of the total in the family). Proportionally fewer New World species have been studied (Goldblatt and Takei, 1997; Goldblatt, 1982).

Karyological data are available for only nine species from northeastern Brazil. This shortage of data represents an important gap in our knowledge of chromosome variation among the Brazilian representatives of this family and in our understanding of the mechanisms of karyotype evolution in this plant group.

Send correspondence to Lânia Isis Ferreira Alves. Laboratório de Citogenética Vegetal, Setor de Botânica, Departamento de Ciências Biológicas, Universidade Federal da Paraíba, Campus II, 58.397-000 Areia, PB, Brazil. E-mail: laniaisis@yahoo.com.br.
In the present study we investigated the mechanisms of chromosome evolution in different groups of Iridaceae from northeastern Brazil by examining the chromosome morphologies of 15 species from five genera of the tribes Trimezieae and Tigrideae (Iridoideae). Karyograms were prepared for 10 species and their karyotypic asymmetry indices were calculated.

\section{Materials and Methods}

Chromosome numbers, previously published and new reports of diploid numbers, plant origins and voucher numbers of all of the populations and taxa examined are presented in Table 1. The plants were grown in plastic containers in a 1:1 mixture of washed sand and agricultural soil. The species were collected in the field in six states in northeastern Brazil, except for Neomarica glauca (collected in Minas Gerais State, southeastern Brazil) and one population of Trimezia connata (collected in Pará State, northern Brazil). All the specimens collected were deposited in the herbarium Jayme Coelho de Morais of UFPB (EAN) (Table 1).

Chromosome analyses were performed using root tips pretreated with $0.002 \mathrm{M} 8$-hydroxyquinoline at $4{ }^{\circ} \mathrm{C}$ for $24 \mathrm{~h}$. The material was then mixed in absolute ethanol/glacial acetic acid $(3: 1 \mathrm{v} / \mathrm{v})$ for $3-24 \mathrm{~h}$ at room temperature $\left(25^{\circ} \mathrm{C}\right)$ and stored at $-20^{\circ} \mathrm{C}$. To prepare slides for analysis, root tips were hydrolyzed in $5 \mathrm{~N} \mathrm{HCl}$ at room temperature, frozen in liquid nitrogen to remove the coverslip, stained with Giemsa 2\% for $15 \mathrm{~min}$, and mounted in Entellan (Fukui, 1996). Chromosome measurements were made in 
Table 1 - Diploid numbers of some Iridaceae species from the Brazilian Northeast. Diploid numbers indicated in bold were reported herein.

\begin{tabular}{|c|c|c|c|c|c|c|}
\hline Taxon & Locality $^{1}$ & Voucher number ${ }^{2}$ & $2 n$ & Figures & $\begin{array}{c}\text { Previously } \\
\text { reported } 2 n\end{array}$ & Source \\
\hline \multicolumn{7}{|l|}{ Tribe Tigrideae Baker } \\
\hline \multicolumn{7}{|l|}{ Alophia Herb. } \\
\hline \multirow[t]{3}{*}{ A. drummondii (Graham) R.C. Foster } & Esperança, PB & LPFelix, 11186 & 28,56 & $1 \mathrm{a}, \mathrm{b}$ & 28 & \\
\hline & Pariconha, AL & LPFelix, 12169 & 42 & $1 \mathrm{c}, 3 \mathrm{~b}$ & - & GT97 \\
\hline & Itapiúna, CE & LPFelix, 10004 & $14+1 \mathrm{~B}$ & $1 \mathrm{~d}, 3 \mathrm{a}$ & - & - \\
\hline
\end{tabular}

Cipura Aubl.

C. paludosa Aubl.

C. xanthomelas Maxim. ex Klatt

\section{Eleutherine Herb.}

E. bulbosa (Mill) Urb.

N. glauca (Seub. ex Klatt) Sprague

$N$. gracilis (Herb.) Sprague

N. humilis (Klatt) Capell.

N. northiana (Schneev.) Sprague

N. cf. paradoxa (Ravenna) Chukr

Neomarica $\mathrm{sp}$

Trimezia Salisb. ex Herb.

T. connata Ravenna

T. fosteriana Steyerm.

T. martinicensis (Jacq.) Herb.

Areia, PB
Itapororoca, PB
Campo Maior, PI
Castelo, PI

Campo Maior, PI

Areia, PB

Taquaritinga do Norte,

PE

Ilha Comprida, SP

Instituto Agronômico de IAC, 82221

Campinas, SP

\section{Areia, PB \\ Salto da Divisa, MG}

Serra de Itabaina, SE

Guaramiranga, CE

Maranguape, $\mathrm{CE}$

Ibateguara, AL

Campina Grande, PB

Recife, PE

Belém, PA

Morro do Chapéu, BA

Caruaru, PE

Areia, PB

Belém, PA

Recife, PE

João Pessoa, PB

Brejo da Madre de Deus, PE
LPFelix, 10739

LPFelix, 10732

LPFelix, 11032

LPFelix, 11059

28

LPFelix, 11025

LPFelix, 10654

12

$1 \mathrm{~g}, 3 \mathrm{e}$

12,14

G82; KH84;

G91; BG90;

GT97

KH84; G82;

BG90; GT97

GH87
LPFelix, 12000

LPFelix, 12802

18

$$
\text { 2a, 4a }
$$

NAPorto, $\mathrm{S} / \mathrm{N}$

LPFelix, 12762

LPFelix, 10805
LPFelix, 12002

LPFelix, 12743

LPFelix, 10740

LPFelix, 10055

LPFelix, 12003

LIFAlves, 02

LPFelix, S/N

LPFelix, 12671

LPFelix,11691

28

2g, 4f

LPFelix, S/N

18

LPFelix, 11966

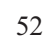

$2 \mathrm{j}$

LIFAlves, 01

52

54

$2 b$
$2 c$
$2 d, 4 b$

$2 \mathrm{e}, 4 \mathrm{c}$

2f, $4 \mathrm{~d}$

$2 \mathrm{~h}, 4 \mathrm{e}$

LPFelix, 11185

21

21

24,32
-
-

G82; KH84; GT97

\footnotetext{
${ }^{1}$ The Brazilian states are abbreviated as: $\mathrm{PB}=$ Paraíba, $\mathrm{CE}=$ Ceará, $\mathrm{MG}=$ Minas Gerais, $\mathrm{AL}=$ Alagoas, $\mathrm{PE}=\mathrm{Pernambuco}, \mathrm{BA}=\mathrm{Bahia}, \mathrm{PI}=\mathrm{Piaui}$. ${ }^{2}$ Voucher deposited in herbarium Jayme Coelho de Morais (EAN). ${ }^{3}$ Sources abbreviations: GT97 = Goldblatt and Takei (1997); KH84 = Kenton and Heywood (1984); G82 = Goldblatt (1982); GB90 = Beltrão and Guerra (1990); GH87 = Goldblatt and Henrich (1987); G91 = Guerra (1991).
} 
the best spreads. The terminologies for interphase nuclei and prophase condensation patterns were adapted from Benko-Iseppon and Morawetz (2000) and Yokota (1990), respectively. The material was photographed using an Olympus BX41 microscope equipped with an Olympus D-54 digital camera.

At least five metaphases were analyzed per population to determine the chromosome numbers and the three best cells were used for measuring chromosome lengths and for making the karyograms. The karyograms were organized in order of chromosome size. All measurements were performed using the Image Tool software program. The lengths of the short (s) and long arms $(l)$ as well as the centromeric indices $(\mathrm{CI}=100 \mathrm{~s} / \mathrm{s}+l)$ were determined, and the data were organized in decreasing size order. The chromosome nomenclature used was $\mathrm{M}$ for metacentrics $(\mathrm{CI}=50.0-40.1)$, SM for submetacentrics ( $\mathrm{CI}=40.0-25.1)$, A for acrocentrics $(\mathrm{CI}=25.1-0.01)$ and $\mathrm{T}$ for telocentrics $(\mathrm{CI}=0.00)$. The following karyological parameters were determined: total chromosome length (TCL), mean chromosome length (CL), and the ratio between the largest and the smallest chromosomes $(\mathrm{L} / \mathrm{s})$. Karyotypic asymmetry was evaluated using the interchromosomal asymmetry index $\left(\mathrm{A}_{2}\right)$ proposed by Romero Zarco (1986) and the classification followed Stebbins (1971). The intrachromosomal asymmetry index $\left(A_{1}\right)$ of Romero Zarco (1986) was not used because it was incompatible with the karyotypes studied.

\section{Results}

All species had semi-reticulated interphase nuclei (Figures 1b, c and 2c) with few interspecific differences in chromatin density or chromocenter sizes. The chromosome numbers varied from $2 n=12$ in Eleutherine bulbosa to $2 n=82$ in Trimezia connata, and the mean chromosome sizes varied from 1.03 (Neomarica cf. paradoxa and $T$. martinicensis) to $5.89 \mu \mathrm{m}$ (Neomarica northiana), with a predominance of meta- and submetacentric chromosomes. The genus Neomarica had the highest number of chromosomes with satellites, varying from two to six among the different species. In relation to the interchromosomal

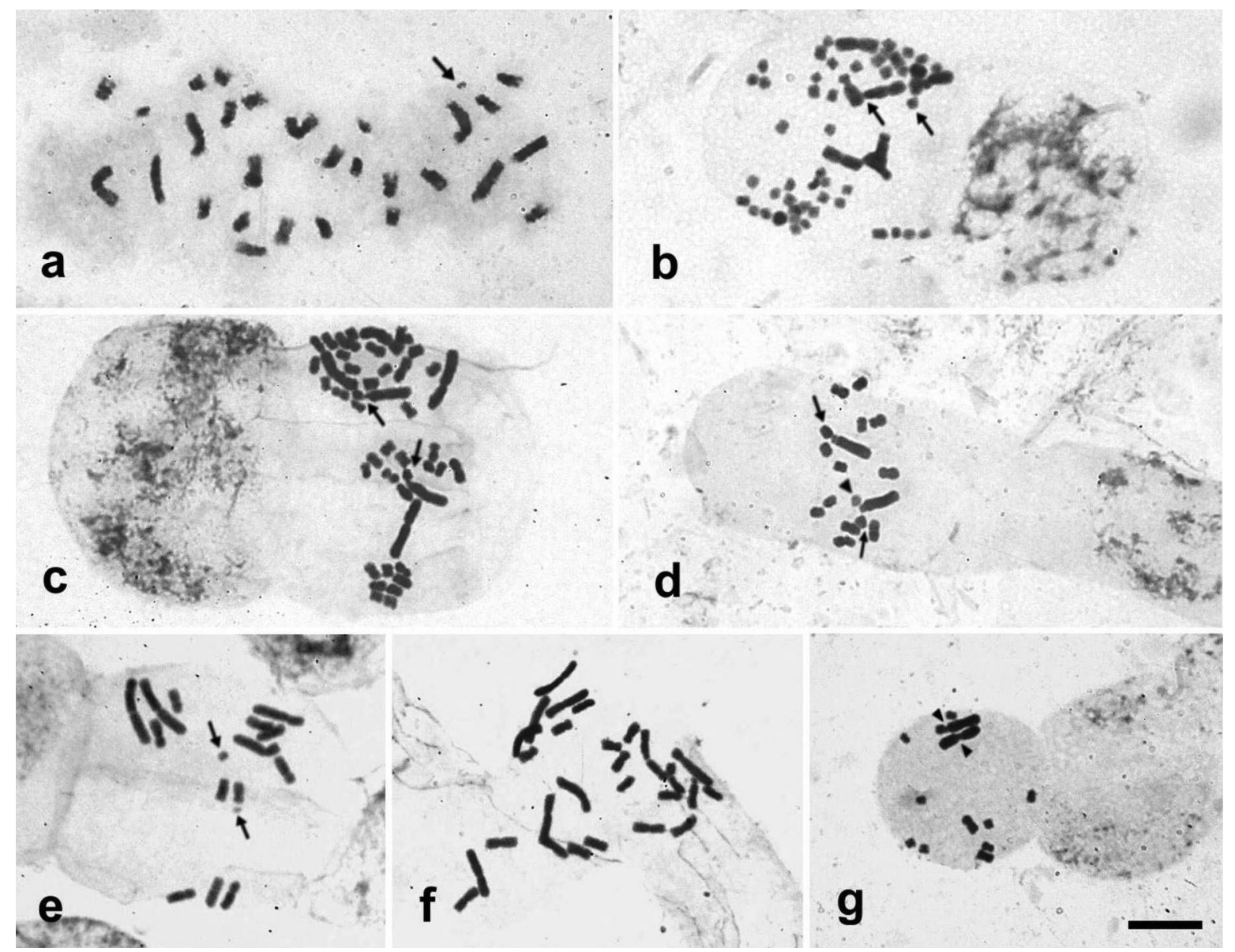

Figure 1 - Mitotic metaphase and interphase nuclei of species of the Tribe Tigrideae from northeastern Brazil: (a-d) Alophia drummondii with (a) $2 n=28$ and one visible satellite; (b) $2 n=56$ and two satellites and (c) $2 n=42$ and one satellited pair; (d) $2 n=14+1 \mathrm{~B}$ with a pair of distended satellites and a heteropicnotic B chromosome (arrowhead); (e) Cipura paludosa with $2 n=14$ and a pair of distended satellites; (f) Cipura xanthomelas with $2 n=28$; (g) Eleutherine bulbosa $(2 n=12)$ with a distended secondary constriction (arrowhead). Arrows indicate satellites in (a), (b), (c), (d) and (e). The bar corresponds to $10 \mu \mathrm{m}$. 


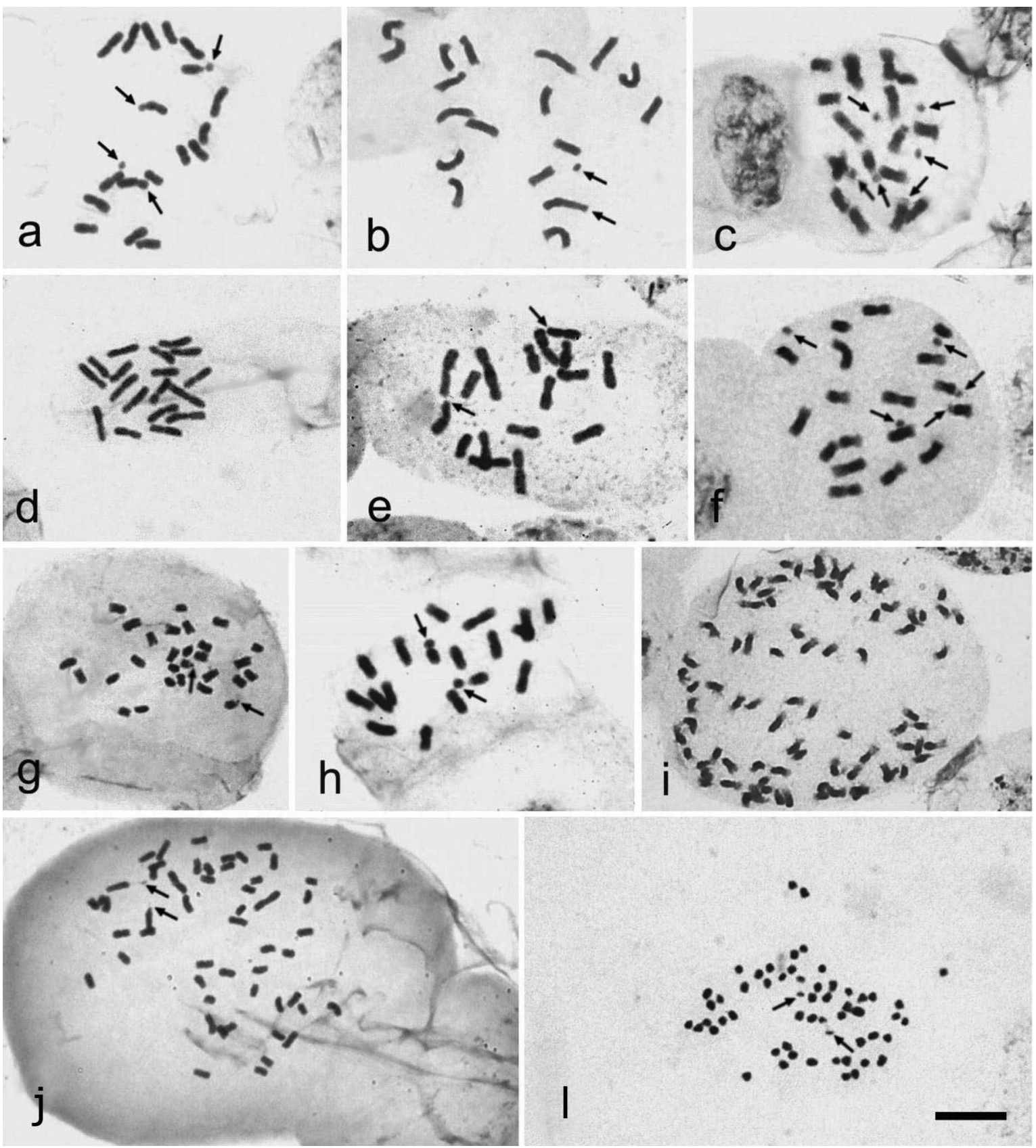

Figure 2 - Mitotic metaphase and interphase nuclei of species of the Tribe Trimezieae from northeastern Brazil: (a) Neomarica candida with $2 n=18$ and four satellites; (b) $N$. caerulea with $2 n=18$ and two satellites; (c) $N$. glauca with $2 n=18$ and six satellites; (d) $N$. gracilis $(2 n=18) ;$ (e) $N$. humilis $(2 n=18)$ with one satellited pair; (f) $N$. northiana with $2 n=18$ and five satellites; (g) $N$. cf. paradoxa with $2 n=28$ and two satellites; (h) Neomarica sp. with $2 n=18$ and two satellites; (i) Trimezia connata with $2 n=82$; (j) T. fosteriana with $2 n=52$ and a pair of terminal satellites; (1) T. martinicensis with $2 n=54$ and a distended pair of satellites. Arrows indicate satellites. The bar corresponds to $10 \mu \mathrm{m}$.

asymmetry index $\left(\mathrm{A}_{2}\right)$, Alophia drummondii, Cipura paludosa, C. xanthomelas and Eleutherine bulbosa had asymmetric karyotypes, while Neomarica candida, $N$. caerulea, $N$. humilis, $N$. glauca, $N$. gracilis, $N$. northiana, Neomarica sp., $N$. cf. paradoxa, Trimezia connata, $T$. fosteriana, and T. martinicensis had symmetric karyotypes.

The diploid numbers of all of the species examined are summarized in Table 1. The karyotypic formula and other morphometric parameters of the 15 species examined are presented in Table 2. Figures 1 and 2 show the mitotic metaphases of the species analyzed, and the karyograms of ten species are illustrated in Figures 3 and 4. Analyses of the main karyotypic features of the species studied are detailed below:

\section{Tribe Tigrideae}

All the species examined from this tribe had bimodal and asymmetric karyotypes, with one or more chromosome 
Table 2 - List of analyzed species and their karyotypic formula, total chromosome length (TCL), mean chromosome length (CL), mean centromere index (CI), interchromosomal asymmetry index (A2), proportion between the largest and smallest chromosomes (L/s), Stebbins asymmetry category (Steb.).

\begin{tabular}{|c|c|c|c|c|c|c|c|}
\hline Taxon & Karyotypic formula & TCL $(\mu \mathrm{m})$ & $\mathbf{C L}(\mu \mathrm{m})$ & CI (\%) & $\mathbf{A}_{2}$ & $\mathbf{L} / \mathbf{s}$ & Steb \\
\hline \multicolumn{8}{|l|}{ Tribe Tigrideae } \\
\hline \multicolumn{8}{|l|}{ Alophia } \\
\hline \multirow[t]{2}{*}{ Alophia drummondii } & $38 \mathrm{M}+2 \mathrm{SM}+2 \mathrm{~A}$ & $98.76 \pm 1.66$ & 2.35 & 42.30 & 0.70 & 6.67 & $3 c$ \\
\hline & $(10 \mathrm{M}+4 \mathrm{SM})+1 \mathrm{~B}$ & $20.28 \pm 0.91$ & 1.45 & 43.10 & 0.63 & 2.84 & $3 \mathrm{c}$ \\
\hline \multicolumn{8}{|l|}{ Cipura } \\
\hline Cipura paludosa & $4 \mathrm{M}+2 \mathrm{SM}+8 \mathrm{~A}$ & $67,81 \pm 2,41$ & 4.84 & 39.01 & 0.50 & 4.28 & $3 \mathrm{c}$ \\
\hline C. xanthomelas & $10 \mathrm{M}+8 \mathrm{SM}+10 \mathrm{~A}$ & $117.68 \pm 2.32$ & 4.10 & 38.70 & 0.55 & 2.28 & $3 \mathrm{c}$ \\
\hline \multicolumn{8}{|l|}{ Eleutherine } \\
\hline E. bulbosa & $11 \mathrm{M}+1 \mathrm{~A}$ & $31.34 \pm 2.02$ & 2.62 & 41.92 & 0.77 & 5.00 & $3 \mathrm{c}$ \\
\hline \multicolumn{8}{|l|}{ Tribe Trimezieae } \\
\hline \multicolumn{8}{|l|}{ Neomarica } \\
\hline N. candida & $4 \mathrm{M}+8 \mathrm{SM}+6 \mathrm{~A}$ & $72.29 \pm 0.68$ & 4.02 & 36.93 & 0.16 & 1.86 & $3 a$ \\
\hline N. caerulea & $10 \mathrm{M}+6 \mathrm{SM}+2 \mathrm{~A}$ & $80.34 \pm 0.71$ & 4.46 & 38.98 & 0.16 & 1.78 & $3 \mathrm{a}$ \\
\hline N. glauca & $8 \mathrm{M}+6 \mathrm{SM}+4 \mathrm{~A}$ & $66.11 \pm 0.58$ & 3.67 & - & 0.13 & 1.43 & - \\
\hline N. gracilis & $6 \mathrm{M}+8 \mathrm{SM}+4 \mathrm{~A}$ & $83.44 \pm 0.53$ & 4.64 & 41.12 & 0.11 & 1.41 & \\
\hline N. humilis & $14 \mathrm{M}+2 \mathrm{SM}+2 \mathrm{~A}$ & $98.71 \pm 0.97$ & 5.48 & 40.30 & 0.18 & 1.82 & $3 \mathrm{a}$ \\
\hline N. northiana & $16 \mathrm{M}+2 \mathrm{SM}$ & $106.13 \pm 0.87$ & 5.89 & 44.29 & 0.15 & 1.61 & $3 a$ \\
\hline N. cf. paradoxa & $20 \mathrm{M}+8 \mathrm{SM}$ & $28.94 \pm 0.13$ & 1.03 & - & 0.12 & 1.78 & - \\
\hline Neomarica sp. & $8 \mathrm{M}+6 \mathrm{SM}+4 \mathrm{~A}$ & $86.25 \pm 0.58$ & 4.79 & 41.98 & 0.18 & 1.54 & $3 a$ \\
\hline Trimezia & & & & & & 2.06 & \\
\hline T. connata & - & $182.86 \pm 0.65$ & 2.23 & - & 0.29 & 2.83 & - \\
\hline T. fosteriana & - & $104.61 \pm 0.52$ & 2.02 & - & 0.25 & 2.55 & - \\
\hline T. martinicensis & - & $55.66 \pm 0.17$ & 1.03 & - & 0.16 & 1.83 & - \\
\hline
\end{tabular}

pairs being larger than the rest. Alophia drummondii had $2 n=14+1 \mathrm{~B}, 28,42$ and 56, with one-two satellites located on the short arm of one of the larger metacentric pairs (Figures 1a, b, c, d). One population of $A$. drummondii from Esperança, Paraíba State, had individuals with $2 n=28$ and 56 (Figure 1a, b) with four large chromosome pairs. We were not able to obtain good chromosome condensation, which made centromere visualization difficult, particularly for the smaller chromosomes. The individuals with $2 n=56$ (Figure 1b) showed four large chromosome pairs, two acrocentric and two metacentric, as well as other smaller pairs, varying from meta- to submetacentric, with two satellites located on the larger metacentric pairs. The population of Alophia drummondii from Pariconha, Alagoas State, had $2 n=42$ (Figures 1c, 3b), with three large chromosome pairs and additional smaller pairs, the karyotypic formula was $38 \mathrm{M}+2 \mathrm{SM}+2 \mathrm{~A}$, the chromosomes measured 1.29-6.51 $\mu \mathrm{m}$, and the interchromosomal asymmetry was $\mathrm{A}_{2}=0.70$ (Table 2 , Figure $3 b$ ). The individuals from this population were larger and had larger fruits when compared to the ones with $2 n=28$ and 56, but showed no noticeable differences in their floral morphologies.
One population of Alophia drummondii from Itapiúna, Ceará State, had a strongly asymmetric karyotype, with $2 n=14+1 \mathrm{~B}$ (Figures 1d, 3a), chromosomes measuring 1.97-5.61 $\mu \mathrm{m}$ (karyotypic formula 10M+4SM+1B), and interchromosomal asymmetry $\mathrm{A}_{2}=0.63$. It was included in the category $3 \mathrm{c}$ from Stebbins. This population had lighter colored flowers, but the floral morphologies did not noticeably differ from the other population of the species. Two distended satellites with proximal secondary constrictions were observed on the large acrocentric pair (Figure 3a). The supernumerary chromosome was smaller and heteropycnotic when compared to the other chromosomes in the complement and it was not observed in the other $A$. drummondii cytotypes.

Cipura paludosa has $2 n=14$, chromosomes measuring 2.21 to $9.48 \mu \mathrm{m}$ (Figures 1e, 3c), and the karyotypic formula $4 \mathrm{M}+2 \mathrm{SM}+8 \mathrm{~A}$, with two satellites located on the smaller submetacentric pair. Heteromorphisms in submetacentric pairs I and II due to differences in the sizes of the long arms was observed in all populations (Figure $3 \mathrm{c}$ ). This species showed interchromosomal asymmetry $\mathrm{A}_{2}=0.50$ and was thus classified into category $3 \mathrm{c}$ from Stebbins (Table 2). In contrast, $C$. xanthomelas was tetraploid with 
$2 n=28$ (Figures 1f, 3d) and had 2.64 to $6.02 \mu \mathrm{m}$ long metaand submetacentric chromosomes, with a karyotypic formula $10 \mathrm{M}+8 \mathrm{SM}+10 \mathrm{~A}$, interchromosomal asymmetry $\mathrm{A}_{2}=0.55$ and no visible satellites (Table 2, Figure 3d). Eleutherine bulbosa had $2 n=12$ (Figures $1 \mathrm{~g}, 3 \mathrm{e}$ ) and a karyotype composed of $11 \mathrm{M}+1 \mathrm{~A}$. The largest chromosome pair was heteromorphic, with one metacentric and one acrocentric chromosome. This species had a strongly asymmetric karyotype, chromosomes measuring 1.36 to $6.80 \mu \mathrm{m}$, an interchromosomal asymmetry index $\mathrm{A}_{2}=0.77$ and was included in category $3 \mathrm{c}$ from Stebbins (Table 2, Figure 3e).

\section{Tribe Trimezieae}

Neomarica candida, N. caerulea, N. humilis, N. glauca, $N$. gracilis, $N$. northiana, and Neomarica sp. had $2 n=18$, whereas $N$. cf. paradoxa had $2 n=28$ (Table 1). Although $N$. cf. paradoxa differed in chromosome numbers and sizes, the other species of Neomarica had small differences in their karyotypic formula and chromosome sizes, but always had a predominance of meta- and submetacentric chromosomes (Table 2). The mean chromosome lengths varied from $1.03 \mu \mathrm{m}$ in Neomarica cf. paradoxa to $5.89 \mu \mathrm{m}$ in $N$. northiana with two, four, or six satellites. $N$. candida had the karyotypic formula $4 \mathrm{M}+8 \mathrm{SM}+6 \mathrm{~A}$, chromosomes measuring 3.66-5.69 $\mu \mathrm{m}$, and four to six satellites located on meta- and submetacentric chromosomes (Figures $2 \mathrm{a}$ and $4 \mathrm{a}$ ). $N$. caerulea had $10 \mathrm{M}+6 \mathrm{SM}+2 \mathrm{~A}$, chromosomes 3.35 to $5.64 \mu \mathrm{m}$ long and two satellites located on the short arms of metacentric chromosomes (Figure 2b). $N$. glauca $(8 \mathrm{M}+6 \mathrm{SM}+4 \mathrm{~A})$ had chromosomes measuring 2.51 to $4.58 \mu \mathrm{m}$ and two to four satellited pairs (Figure 2c); $N$. gracilis $(6 \mathrm{M}+8 \mathrm{SM}+4 \mathrm{~A})$ had chromosomes measuring 3.87 to $4.76 \mu \mathrm{m}$ and no satellites were observed (Figures $3 \mathrm{~d}$ and $4 \mathrm{~b})$; and in $N$. humilis $(14 \mathrm{M}+2 \mathrm{SM}+2 \mathrm{~A})$ chromosome sizes varied from 3.72 to $6.76 \mu \mathrm{m}$, with one satellited pair (Figures $2 \mathrm{e}$ and $4 \mathrm{c}) . N$. northiana had $16 \mathrm{M}+2 \mathrm{SM}$, chromosomes measuring 4.57 to $7.33 \mu \mathrm{m}$, and two to six satellites were observed on the short arms of the meta- and acrocentric chromosomes (Figures $2 \mathrm{f}$ and $4 \mathrm{~d}$ ). In Neomarica sp., chromosome sizes varied from 5.81 to $6.45 \mu \mathrm{m}$, with one pair of satellites and the karyotypic formula was $8 \mathrm{M}+6 \mathrm{SM}+4 \mathrm{~A}$ (Figures $2 \mathrm{~h}$ and $4 \mathrm{e}$ ). $N$. cf. paradoxa had the karyotypic formula $20 \mathrm{M}+8 \mathrm{SM}$, chromosomes measuring 0.98 to $2.77 \mu \mathrm{m}$, with one or two satellites. This species was different from the others in diploid number and in the smaller size of its chromosomes (Figures $2 \mathrm{~g}$ and $4 \mathrm{f}$ ). Interchromosomal asymmetry $\left(\mathrm{A}_{2}\right)$ varied from 0.11 in $N$. gracilis to $0.18 \mu \mathrm{m}$ in $N$. northiana and Neomarica sp., all included in the 3a asymmetry category from Stebbins (1971), which corresponds to relatively symmetric karyotypes (Table 2).

The Trimezia species studied herein had symmetric karyotypes composed of small chromosomes, with mean a

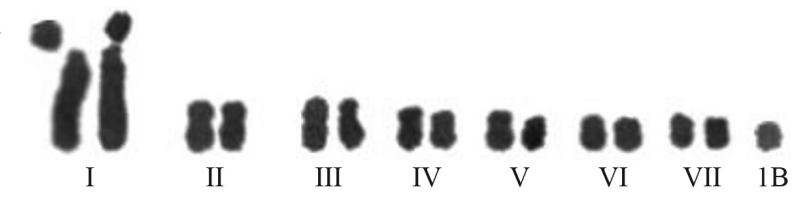

b
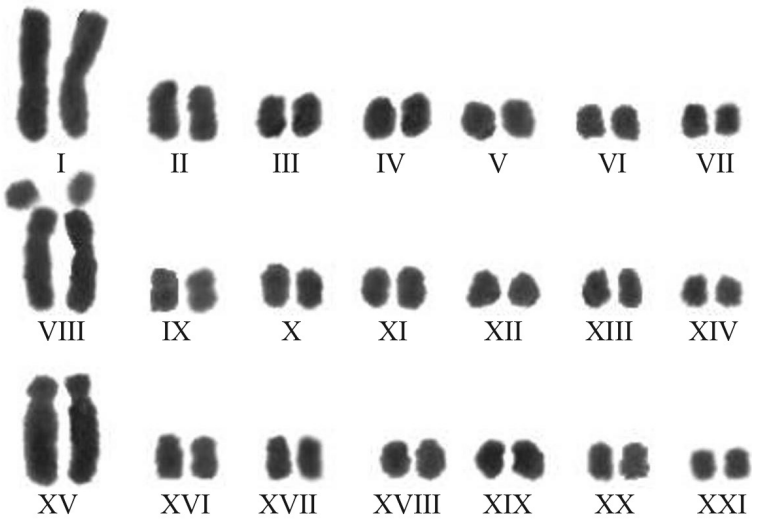

c

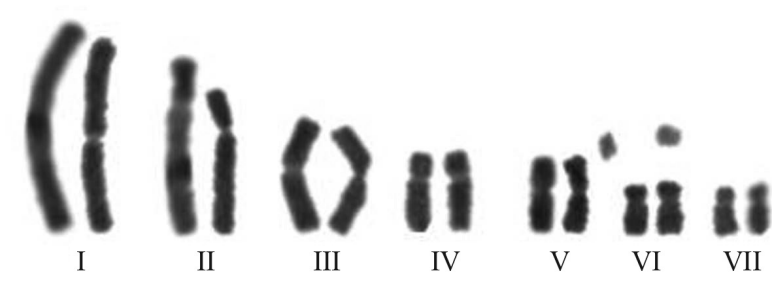

d

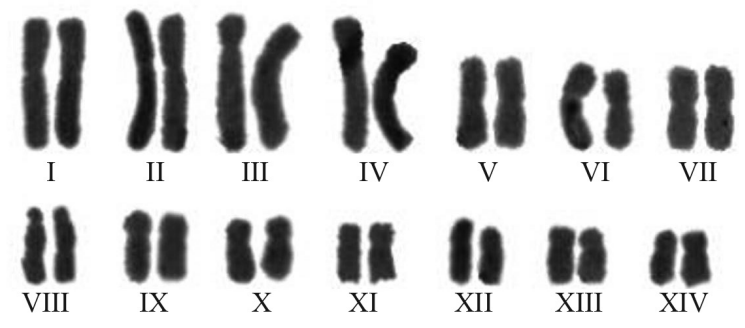

e

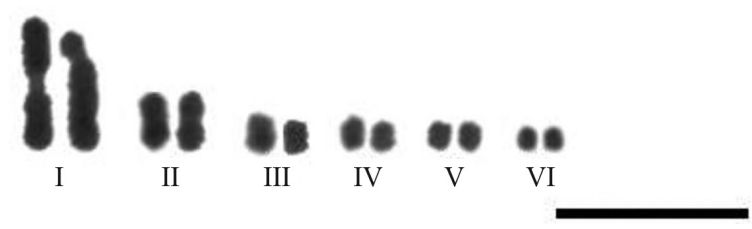

Figure 3 - Karyograms of some species of the Tribe Tigrideae from northeastern Brazil. (a-b) Alophia drummondii: (a) $2 n=14+1 \mathrm{~B}$ and (b) $2 n=42$; (c) Cipura paludosa $(2 n=14)$; (d) C. xanthomelas $(2 n=28)$; (e) Eleutherine bulbosa $(2 n=12)$. The bar corresponds to $10 \mu \mathrm{m}$.

chromosome lengths varying from $1.03 \mu \mathrm{m}$ ( $T$. martinicensis) to $2.23 \mu \mathrm{m}$ (T. connata), with distended or terminal satellited pairs. Populations of Trimezia connata from Areia (Paraíba State) and Belém (Pará State) had $2 n=82$ (Table 1, Figure 2i), small chromosomes without visible secondary constrictions and no satellites were observed. Trimezia fosteriana had $2 n=52$, with a pair of satellites and terminal secondary constrictions in the plants from Recife (Pernambuco State) and João Pessoa (Paraíba State) (Table 1, Figure 2j). Trimezia martinicensis had $2 n=54$ in all individuals from a single wild population at 
a

III I I i if II II \& $\|$

b

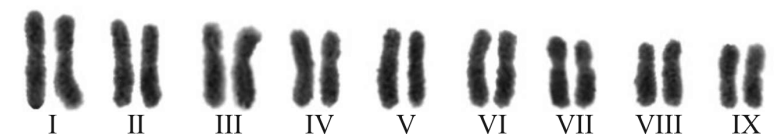

c

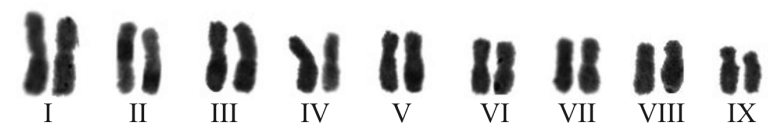

2

e

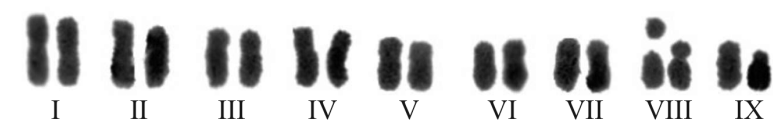

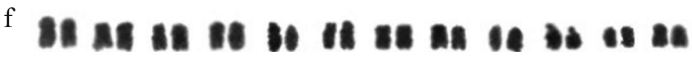

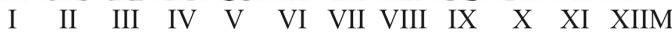
00

XIII XIV

Figure 4 - Karyograms of some species of the Tribe Trimezieae from northeastern Brazil. (a) Neomarica candida; (b) N. gracilis; (c) N. humilis; (d) N. northiana; (e) Neomarica sp. $(2 n=18)$; (f) N. cf. paradoxa $(2 n=28)$. The bar corresponds to $10 \mu \mathrm{m}$.

Brejo da Madre de Deus (Table 1, Figure 21), with a proximal secondary constriction on one chromosome pair.

\section{Discussion}

The Iridaceae are variable in chromosome numbers, sizes and morphologies, with numbers ranging from $2 n=6$ in Crocus candilus (Brighton, 1976) to $2 n=$ ca. 230 in Libertia grandiflora (Kenton and Heywood, 1984). Such variability may be related to cycles of polyploidy and disploidy reduction in both Neotropical (Goldblatt et al., 1998) and Old World species (Goldblatt and Takei, 1993). Disploidy and aneuploidy appear to have had an important role in the chromosome evolution of this family, especially among the Tigridioideae. In our study, heteromorphisms of the long arms of the large chromosomes of Cipura paludosa $(2 n=14)$ suggested the presence of reciprocal translocations. Sengupta and Sen (1988) reported heteromorphism in a single large chromosome pair in several specimens of $C$. paludosa, including hybrids and callus tissue cultivated in vitro, and a predominance of $2 n=12$. Chromosome heteromorphisms have been occasionally reported in the Iridaceae, especially in the Tigrideae, with previous records for Eleutherine bulbosa in pair I due to an inversion followed by tandem duplications (Guerra, 1991), as well as for Gelasine elongata (R. Graham) Ravenna (formerly Gelasine azurea) as a result of a complex series of translocation events (Kenton and Rudall, 1987). The precise identification of the structural changes involved in these heteromorphisms will only be possible after meiotic analyses or after the use of differential staining techniques that reveal more detailed chromosome features (Alves, in preparation).

\section{Inter- and intraspecific chromosome numerical variations}

The finding of $2 n=28$ for Alophia drummondii (Tigrideae) agrees with previous reports for this species in North America (Goldblatt and Takei, 1997; Kenton and Heywood, 1984), but diverges from the other diploid numbers found in this species, $2 n=14+1 \mathrm{~B}, 2 n=42$ and $2 n=56$. The karyotypes of the North American populations have two large chromosome pairs (one meta- and one acrocentric), in contrast to the cytotypes with $2 n=28$ and 56, that show four larger chromosome pairs (two metacentric and two acrocentric pairs) and of the cytotypes with $2 n=42$ that have three larger chromosomes pairs (two metacentric and two acrocentric).

Our record of $2 n=14+1 \mathrm{~B}$ for Alophia drummondii is new for this genus and confirms the basic number $\mathrm{x}=7$ for this taxon, as was also observed in other genera of Tigrideae (Goldblatt and Takei, 1997; Goldblatt and Snow, 1991). This data suggest that $A$. drummondii originated from a species with a low chromosome number that formed cytotypes with $2 n=28,42$ and 56 through successive polyploidy cycles. B chromosomes, which were probably suppressed in the polyploid cytotypes, were also reported in southern Brazilian forms of the genus Herbertia (Goldblatt, 1982).

The karyotypic differences between these disjunct populations of $A$. drummondii (as well as some of the individuals from the Esperança population in Paraíba State) suggest that structural karyotypic changes, in addition to polyploidy, would best explain the karyotypic evolution of this species and the maintenance of its bimodality. Other species of the family exhibit intraspecific polyploidy, such as Gladiolus italicus with $2 n=60,90,110-120$ (Raamsdonk and De Vries, 1989) and Iris japonica with $2 n=18$, 30, 32, 36, 60 (Zhou et al., 2003). In Lapeirousia (an African genus that also shows high bimodality), karyotypic differences seem to have originated from chromosome fusions and from the loss of redundant centromeres, resulting in increases in chromosome size and reductions in diploid numbers without significant variation in genome size (Goldblatt and Takei, 1997, 1993). The differences in the numbers and morphologies of the large chromosome pairs observed in the population of $A$. drummondii examined herein indicate that structural changes occurred during the karyotypic evolution of this species. Robertsonian translocations in Ornithogalum tenuifolium (Stedje, 1987) may have resulted in the formation of a chromosome race with $2 n=4$ $(2 n=6 \rightarrow 2 n=4)$.

Trimezia and Neomarica are exclusively New World genera, but their basic chromosome numbers are still uncer- 
tain (Goldblatt et al., 1998). The genus Neomarica exhibited a relatively constant $2 n=18$ in several species in this study, suggesting that this genus is more stable in diploid number than other genera of the tribe Trimezieae. However, Neomarica cf. paradoxa $(2 n=28)$ is karyologically and morphologically distinct from the other species of the genus, and appears to be very similar to Trimezia both morphologically and cytologically.

The $2 n=82$ populations of $T$. connata from the states of Paraíba and Pará (from forested areas) are reported herein for the first time. This species is similar in size and morphology to T. martinicensis with $2 n=80$, as observed by Goldblatt and Takei (1997). These two species are very similar in terms of their vegetative and floral morphology, so that misidentifications are quite possible (see Goldblatt and Takei, 1997). However, the presence of $T$. connata and T. martinicensis in very distinct ecological environments, together with their karyotypic differences, suggest that these populations should be considered different species (perhaps cryptospecies). Differences in the location of the rDNA sites and in the satellites between diploid and tetraploid cytotypes of Crocus vernus suggest that their cytotypes are not directly related and that they could in fact represent different species (Frello and Heslop-Harrison, 2000).

Previous reports of $2 n=26$ for $T$. fosteriana (Goldblatt and Takei, 1997), a frequently cultivated species (Lorenzi and Souza, 2001), diverge from our result of $2 n=52$ for plants from Pernambuco and Paraíba. The $2 n=54$ in the population of T. martinicensis from Pernambuco State was similar to the result reported by Kenton and Heywood (1984) for a similar population from southern Brazil, but our results differed from those reported for populations from Jamaica and Martinique, with $2 n=40$ (Kenton and Heywood, 1984), and from Venezuela, with $2 n=80$ (Goldblatt and Takei, 1997). Further analyses are needed in Trimezia to assess its basic chromosome number.

\section{Karyological features of the groups studied}

The basic chromosome numbers of the New World Trimezieae (which include Neomarica, Trimezia and Peseudotrimezia) are still uncertain (Goldblatt and Takei, 1997). Five species of Trimezia reviewed by Goldblatt and Takei (1997) had variable diploid numbers $(2 n=26,28,40$, $52,54,60,76$ and 80 ) and variable chromosome sizes and morphologies (Kenton and Heywood, 1984). The occurrence of polyploidy cycles, followed by increasing or decreasing disploidy makes it difficult to determine the basic number in this group. Neomarica and Trimezia (Trimezieae) have symmetric karyotypes, but Neomarica is numerically more stable. The previous records of $2 n=18$ for $N$. northiana were confirmed in our Neomarica sample. However, the previous reports of $2 n=24$ and 32 for $N$. caerulea (Goldblatt and Takei, 1997; Kenton and Heywood, 1984; Goldblatt, 1982) did not agree with our results for any of the species studied, which had $2 n=18$ or $2 n=28$ in $N$. cf. paradoxa (and unusually small chromosomes). The diploid number variations previously reported, as well as our own data, support $\mathrm{x}=9$ or 8 as the probable basic number for Neomarica (Goldblatt et al., 1998). Our data, as well as the presence of an erect rhizome in N.cf. paradoxa, suggest that its inclusion in Neomarica should be reconsidered (as well as the inclusion of other species with similar underground organs).

The karyotypes of Tigrideae reported herein, as well as those of other genera (Kenton and Heywood, 1984), are clearly asymmetric, bimodal, and show two to eight large meta-acrocentric chromosome pairs, while the remaining pairs are small and predominantly metacentric. Populations of Eleutherine bulbosa from Central America have karyotypes that are more symmetrical than those of the populations from northeastern Brazil (Guerra, 1991), which suggests that the latter may have originated from an ancestral stock with a symmetric karyotype (Chiarini, 2005; Stebbins, 1971). In the other species, as well as in Lapeirousia (Goldblatt and Takei, 1997), unequal translocations could have caused the bimodality seen and these may offer evolutionary advantages in cases of ecological alterations (Levin, 2002).

Karyotype asymmetry indices have been widely used to infer mechanisms of chromosomal evolution in plants (Paszko, 2006) (especially the interchromosomal asymmetry index $\left.\left[\mathrm{A}_{2}\right]\right)$. This index provided a good measure of the general morphology of the chromosome sets of the species analyzed herein. The $\mathrm{A}_{2}$ index suggests that the members of Tigrideae seem to have a more clearly derived karyotype than the individuals of Trimezieae, which is confirmed by important synapomorphies, such as plicate leaves, a distinctive type of bulb and the derived $\mathrm{x}=7$ (Goldblatt, 1990). This view is also supported by recent molecular phylogenetic studies of Iridaceae (Goldblatt et al., 2008).

In summary, two karyological groups can be clearly identified in Iridoideae: the tribes Trimezieae, with more symmetric karyotypes and evolution through polyploidy, mainly in Trimezia (with or without disploid variants); and Tigrideae, with asymmetric karyotypes, with occasional heterozygous chromosome pairs.

\section{Acknowledgments}

The authors would like to thank Peter Goldblatt for his collaboration and identification of materials; Antônio Fernando Tombolato from the Instituto Agronômico de Campinas, for kindly providing materials; $\mathrm{CNPq}$ for the financial support and CAPES for a scholarship.

\section{References}

Beltrão GTA and Guerra M (1990) Citogenética de angiospermas coletadas em Pernambuco - III. Cienc Cult 42:839-845 (Abstract in English). 
Benko-Iseppon AM and Morawetz W (2000) Virbunales: Cytological features and a new circumscription. Taxon 49:5-16.

Brighton CA (1976) Cytological problems in the Crocus (Iridaceae) I. The vernus aggregate. Kew Bull 31:33-46.

Chiarini FE (2005) El cariotipo de Ennealophus fimbriatus (Iridaceae). Arnaldoa 12:48-52 (Abstract in English).

Eggers E, Chukr N, Lovo N and Gil A (2010) Iridaceae. In: Forzza RC, Leitman PM, Costa A, de Carvalho Jr. AA, Peixoto AL, Walter BMT, Bicudo C, Zappi D, da Costa DP, Lleras E et al. (eds) Catálogo de Plantas e Fungos do Brasil, v. 2. Instituto de Pesquisa Jardim Botânico do Rio de Janeiro, Rio de Janeiro, pp 1122-1128.

Frello S and Heslop-Harrison JS (2000) Repetitive DNA sequences in Crocus vernus Hill (Iridaceae): The genomic organization and distribution of dispersed elements in the genus Crocus and its allies. Genome 43:902-909.

Fukui K (1996) Plant chromosome at mitosis. In: Fukui K and Nakayama S (eds) Plant Chromosome. Laboratory Methods. CRC Press, Boca Raton, pp 1-17.

Goldblatt P (1982) Chromosome cytology in relation to suprageneric systematics of Neotropical Iridaceae. Syst Bot 7:186198.

Goldblatt P (1990) Phylogeny and classification of Iridaceae. Ann Missouri Bot Gard 77:607-627.

Goldblatt P and Henrich JE (1987) Notes on Cipura (Iridaceae) in South and Central America, and a new species from Venezuela. Ann Missouri Bot Gard 74:333-340.

Goldblatt P and Snow N (1991) Systematics and chromosome cytology of Eleutherine Herbert (Iridaceae). Ann Missouri Bot Gard 78:942-949.

Goldblatt P and Takei M (1993) Chromosome cytology in the tropical African genus Lapeirousia (Iridaceae-Ixioideae). Ann Missouri Bot Gard 80:961-973.

Goldblatt P and Takei M (1997) Chromosome cytology of Iridaceae: Patterns of variation, determination of ancestral base numbers, and modes of karyotype change. Ann Missouri Bot Gard 84:285-304.

Goldblatt P, Mannig JC and Rudall P (1998) Iridaceae. In: Kubitzki K (ed) The Families and Genera of Vascular Plants. Springer, Heidelberg, pp 295-314.

Goldblatt P, Rodriguez A, Powell MP, Davies TJ, Manning JC, van der Bank M and Savolainen V (2008) Iridaceae 'Out of Austalasia'? Phylogeny, biogeography, and divergence time based on plastid DNA sequences. Syst Bot 33:495-508.

Guerra M (1991) Cis-acting regulation of the NOR cistrons in Eleutherine bulbosa (Iridaceae). Genetica 83:235-241.
Judd WS, Campbell CS, Kellogg EA, Stevens PS and Donoghue MJ (2008) Plant systematics: A phylogenetic approach. Sinauer, Sunderland, $611 \mathrm{pp}$.

Kenton A and Heywood CA (1984) Cytological studies in South American Iridaceae. Plant Syst Evol 146:87-104.

Kenton A and Rudall P (1987) An unusual case of complexheterozygosity in Gelasine azurea (Iridaceae), and its implications for reproductive biology. Evol Trends Plants 1:95103.

Levin DA (2002) The Role of Chromosomal Change in Plant Evolution. Oxford University Pess, Oxford, $230 \mathrm{pp}$.

Lorenzi H and Souza HM (2001) Plantas Ornamentais do Brasil: Arbustivas, Herbáceas e Trepadeiras. Instituto Plantarum, São Paulo, 1088 pp.

Paszko B (2006) A critical review and a new proposal of karyotype asymmetry indices. Plant Syst Evol 258:39-48.

Raamsdonk LWD van and De Vries T (1989) Biosystematic studies in European species of Gladiolus (Iridaceae). Plant Syst Evol 165:189-198.

Romero Zarco CR (1986) A new method for estimating karyotype assymetry. Taxon 35:526-530.

Sengupta J and Sen S (1988) Karyological analysis of cultured cells and regenerated plants of Cipura paludosa Aubl. (Iridaceae) A structural hybrid. J Torrey Bot Soc 115:280289.

Stedje B (1987) Chromosome evolution within the Ornithogalum tenuifolium complex (Hyacinthaceae), with special emphasis on the evolution of bimodal karyotypes. Plant Syst Evol 166:79-89.

Stebbins GL (1971) Chromosomal Evolution in Higher Plants. Edward Arnold, London, 216 pp.

Yokota M (1990) Karyomorphological studies on Habenaria, Orchidaceae, and allied genera from Japan. J Sci Hiroshima Univ 23:53-161.

Zhou YH, Wu BH, Yan J, Yang RW, Ding CB and Zhang L (2003) Cytogenetic study on the interspecific hybrid between Iris japonica and Iris confusa (Iridaceae). Acta Bot Yunn 25:497-502.

\section{Internet Resources}

Image Tool (IT) Version 3m0, http://ddsdx.uthscsa.edu/DIG/ download.htm (July 24, 2007).

Associate Editor: Marcelo Guerra

License information: This is an open-access article distributed under the terms of the Creative Commons Attribution License, which permits unrestricted use, distribution, and reproduction in any medium, provided the original work is properly cited. 